Prepared in cooperation with the National Oceanic and Atmospheric Administration

\title{
Bathymetric Terrain Model of the Puerto Rico Trench and the Northeastern Caribbean Region for Marine Geological Investigations
}

Open-File Report 2013-1125 



\section{ॠUSGS \\ science for a changing world}

Prepared in cooperation with the National Oceanic and Atmospheric Administration

\section{Bathymetric Terrain Model of the Puerto Rico Trench and the Northeastern Caribbean Region for Marine Geological Investigations}

By Brian D. Andrews, Uri S. ten Brink, William W. Danforth, Jason D. Chaytor, José-Luis Granja Bruña, Pilar Llanes Estrada, and Andrés Carbó-Gorosabel

Open-File Report 2013-1125

U.S. Department of the Interior

U.S. Geological Survey 


\section{U.S. Department of the Interior \\ SALLY JEWELL, Secretary}

\section{U.S. Geological Survey \\ Suzette M. Kimball, Acting Director}

U.S. Geological Survey, Reston, Virginia: 2014

For more information on the USGS-the Federal source for science about the Earth,

its natural and living resources, natural hazards, and the environment-visit

http://www. usgs.gov or call 1-888-ASK-USGS.

For an overview of USGS information products, including maps, imagery, and publications, visit $h$ ttp://www.usgs.gov/pubprod/.

To order this and other USGS information products, visit $h$ ttp://store.usgs. gov/.

Any use of trade, product, or firm names is for descriptive purposes only and does not imply endorsement by the U.S. Government.

Although this information product, for the most part, is in the public domain, it also may contain copyrighted materials as noted in the text. Permission to reproduce copyrighted items must be secured from the copyright owner.

Suggested citation:

Andrews, B.D., ten Brink, U.S., Danforth, W.W., Chaytor, J.D., Granja Bruña, José-Luis, Llanes Estrada, Pilar, and Carbó-Gorosabel, Andrés, 2014, Bathymetric terrain model of the Puerto Rico trench and the northeastern Caribbean region for marine geological investigations: U.S. Geological Survey Open-File Report 2013-1125, 10 p., 1pl., http://dx.doi.org/10.3133/ofr20131125.

ISSN 2331-1258 (online) 


\section{Acknowledgments}

We thank the Spanish Interministerial Commission of Science and Technology and the Ocean Exploration Trust for supporting surveys 2005-019-FA and 2013-036-FA respectively. We thank the officers and crew of the exploration vessel Nautilus, research vessel Hésperides, and the National Oceanic and Atmospheric Administration ships Ronald $\mathrm{H}$. Brown and Nancy Foster for their skill and assistance during survey operations.

We thank the following U.S. Geological Survey personnel: David Foster and Claudia Flores for constructive comments on earlier drafts, VeeAnn Cross for her comments on metadata, Andrea Toran for her expertise in Web design, and Jonas Casey-Williams for his editorial review. 


\section{Contents}

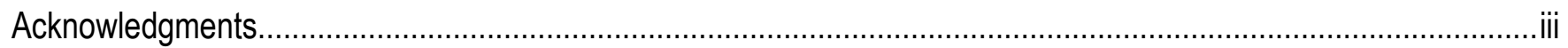

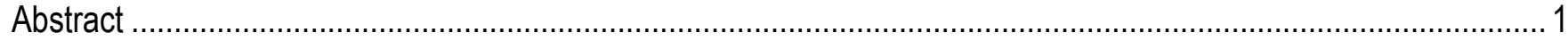

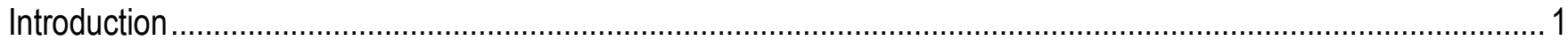

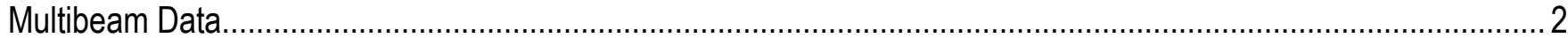

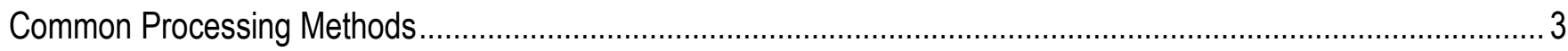

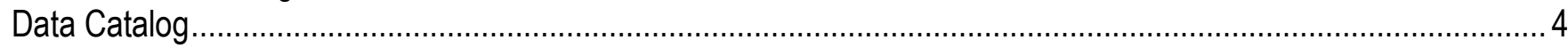

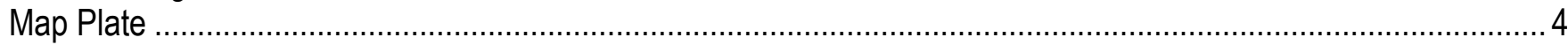

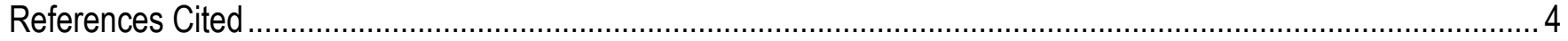

\section{Plate}

[linked separately from http://pubs.usgs.gov/of/2013/1125/]

1. Bathymetry of the Puerto Rico Trench and the Northeastern Caribbean region

\section{Figures}

1. Map showing source surveys (color coded by survey vessel) used to compile the final bathymetric terrain model and published as an Esri shapefile in this report.

2. Diagram showing the general data flow used to process the raw multibeam files into the final data products published in this report.

3. Map of the Puerto Rico Trench and surrounding areas showing the extent of the bathymetric terrain model published in this report. Elevations in tan and gray-scale hillshade (showing the landmasses and the seafloor area outside the study area) are for base map purposes only and not published in the report........9

\section{Table}

1. Bathymetric surveys in the area around the Puerto Rico Trench in the northeastern Caribbean. 10

\section{Conversion Factors, Datums, and Abbreviations}

SI to Inch/Pound

\begin{tabular}{|c|c|c|}
\hline Multiply & By & To obtain \\
\hline \multicolumn{3}{|c|}{ Length } \\
\hline meter $(\mathrm{m})$ & 3.281 & foot (ft) \\
\hline kilometer $(\mathrm{km})$ & 0.6214 & mile (mi) \\
\hline \multicolumn{3}{|c|}{ Area } \\
\hline square kilometer $\left(\mathrm{km}^{2}\right)$ & 0.3861 & square mile $\left(\mathrm{mi}^{2}\right)$ \\
\hline
\end{tabular}

Vertical coordinate information is referenced to instantaneous sea level.

Horizontal coordinate information is referenced to the World Geodetic System of 1984.

The frequency of multibeam bathymetry is measured in kilohertz $(\mathrm{kHz}), 1,000$ periods per second. 


\section{Abbreviations}

3D three-dimensional

ASCII American Standard Code for Information Interchange

BTM bathymetric terrain model

EV exploration vessel

GIS geographic information system

HIPS Hydrographic Information Processing System

NGDC National Geophysical Data Center

NOAA National Oceanic and Atmospheric Administration

RV research vessel

USGS U.S. Geological Survey

UTM Universal Transverse Mercator

WGS $84 \quad$ World Geodetic System 1984 


\title{
Bathymetric Terrain Model of the Puerto Rico Trench and the Northeastern Caribbean Region for Marine Geological Investigations
}

By Brian D. Andrews, ${ }^{1}$ Uri S. ten Brink, ${ }^{1}$ William W. Danforth, ${ }^{1}$ Jason D. Chaytor, ${ }^{1}$ José-Luis Granja Bruña, ${ }^{2}$ Pilar Llanes Estrada, ${ }^{2}$ and Andrés Carbó-Gorosabel ${ }^{2}$

\begin{abstract}
Multibeam bathymetric data collected in the Puerto Rico Trench and northeastern Caribbean region are compiled into a seamless bathymetric terrain model for broad-scale geological investigations of the trench system. These data, collected during eight separate surveys between 2002 and 2013 and covering almost 180,000 square kilometers, are published as a large-format map (plate 1) and digital spatial data. This report describes the common multibeam data collection and processing methods used to produce the bathymetric terrain model and corresponding data-source polygon. Details documenting the complete provenance of the data are provided in the metadata in the Data Catalog section.
\end{abstract}

\section{Introduction}

The Puerto Rico Trench system is the deepest part of the Atlantic Ocean, with water depths exceeding 8,300 meters (ten Brink and others, 2004). It forms a boundary between two tectonic plates, the North American and the Caribbean plates, that mostly slide past each other. However, the North American plate also slides under (or subducts) the Caribbean plate. Similar plate geometry was responsible for the 2004 Sumatra earthquake and tsunami (ten Brink, 2005). The Muertos Trough, with water depths reaching 5,500 meters, is located south of the Dominican Republic, Puerto Rico, and the Virgin Islands. It is an active deformation front, where the islands thrust over the interior Caribbean plate (ten Brink and others, 2009). Mona Passage between Puerto Rico and the Dominican Republic is the site of minor northeast-to-southwest-oriented tectonic extension, which has probably kept it below sea level (Chaytor and ten Brink, 2010). Atlantic surface waters enter the Caribbean Sea through this passage. The Anegada Passage and Virgin Islands Basin between the Virgin Islands and St. Croix and the Lesser Antilles has a complex and poorly understood tectonic deformation history (Barkan and ten Brink, 2010; J.D. Chaytor and U.S. ten Brink, 2014). This passage is the only deep-water passage between the Atlantic Ocean and the Caribbean Sea east of Cuba and is therefore the only location where Atlantic intermediate-depth waters can enter the Caribbean Sea. Destructive historical earthquakes and tsunamis have occurred in the Mona and the Anegada Passages (López-Venegas and others, 2008; Barkan and ten Brink, 2010).

\footnotetext{
${ }^{1}$ U.S. Geological Survey

${ }^{2}$ Universidad Complutense de Madrid
} 
The bathymetric data published in this report were compiled as part of a project funded by the U.S. Geological Survey (USGS), the National Oceanic and Atmospheric Administration (NOAA) Ocean Exploration Program, and the Spanish Interministerial Commission of Science and Technology. The primary purpose of this project is to understand the morphology and underlying tectonics of the region to identify effects of submarine landslides and resulting tsunami hazards that could affect the northeastern Caribbean and the Atlantic coast of the United States. The overall objective of this project is to provide the required geologic information to assess and mitigate tectonic hazards to Puerto Rico, the Virgin Islands, and the east coast of the United States. By determining the likely hazards and their causative mechanisms and providing this information to government agencies and the public, we may aid in such activities as improving building codes, encouraging safer zoning, and assisting public education in responding to hazards (Atwater and others, 2012; Bakun and others, 2012; Barkan and others, 2010; Chaytor and ten Brink, 2010; Flores and others, 2012; ten Brink and López-Venegas, 2012; ten Brink and others, 1999, 2011). This hazards analysis research required a high-quality bathymetric terrain model (BTM) to identify and characterize historical submarine landslides capable of generating tsunamis (López-Venegas and others, 2008; ten Brink and others, 2006a,b).

BTMs of seafloor morphology are an important component of marine geological investigations. Advances in technologies of acquiring and processing bathymetric data have facilitated the creation of high-resolution bathymetric surfaces that approach the resolution of those available for onshore investigations. These BTMs provide a detailed representation of the Earth's subaqueous surface and, when combined with other geophysical and geologic datasets, allow for interpretation of modern and ancient geologic processes.

Beyond the use of the bathymetric compilation in hazard characterization, the BTM provides a spatially consistent dataset for investigating subduction processes that have created the deepest location in the Atlantic Ocean (ten Brink, 2005), large strike-slip south of the subduction zone (ten Brink and Lin, 2004), large normal faults north of the subduction zones (ten Brink and others, 2004), and an active fold-thrust belt south of Puerto Rico (ten Brink and others, 2009).

Purpose and scope. - The purpose of the BTM presented in this report is to provide a highquality bathymetric surface of the Puerto Rico Trench and the northeastern Caribbean region that can be used to augment current and future marine geological investigations. The input data for this BTM, covering almost 180,000 square kilometers, were acquired by several sources, including the USGS, NOAA, the Ocean Exploration Trust, and the Universidad Complutense of Madrid, Spain, between 2002 and 2013. These data have been edited by using hydrographic data processing software to maximize the quality, usability, and cartographic presentation of the combined terrain model.

\section{Multibeam Data}

The multibeam bathymetric data used to produce the BTM in this report were collected during eight separate surveys conducted between 2002 and 2013 (fig. 1). Four of these surveys were conducted on the NOAA Ship Ronald H. Brown, two on the NOAA Ship Nancy Foster, one on the Ocean Exploration Trust's exploration vessel Nautilus, and one on the Spanish research vessel Hésperides (table 1). Data from three of the surveys (2002-051-FA, 2003-008-FA, and 2003-032-FA) conducted on the Ronald H. Brown have been published in ten Brink and others (2013). This report combines the three published multibeam surveys with five unpublished datasets from surveys 2005-019-FA, 2006008-FA, 2007-004-FA, NF-07-04-CRER, and 2013-036-FA. Small differences exist between the data published in ten Brink and others $(2005,2006 \mathrm{c}, 2013)$ and the combined grid published in this report. These differences resulted from additional fine-scale editing of the soundings to increase the 
quality of the final combined grid presented in this report, which supersedes previously published data in ten Brink and others $(2005,2013)$.

\section{Common Processing Methods}

The methods used to access, process and compile the BTM published in this report are described in this section (fig. 2). Multibeam line files were accessed and processed by onboard USGS personnel during the surveys, except for NF-07-05CRER. The line files collected on the Ronald H. Brown and Nancy Foster were archived after completion of the survey with the NOAA National Geophysical Data Center (NGDC). NGDC converted the raw.all files to MB-System format for public access through the NGDC Web site (table 1).

The CARIS Hydrographic Information Processing System (HIPS) was used to process the raw “.all" line files. During each survey, a new HIPS project was made, and the line files for each day (Julian calendar) were imported into the HIPS project. All bathymetric files were collected using instantaneous sea level, and no additional tidal corrections were applied during import into HIPS. Instantaneous sea level indicates that the data were not referenced to a tidal datum; rather, the soundings represent depths that depend on the local sea level at the location and time of measurement. Instantaneous sea level does not correlate to mean sea level; however, for comparison, the total tidal levels (tides, plus no-tidal sea surface heights above the geoid) range between -0.77 meters and 0.81 meters above the geoid for the period 1992-2013 (Egbert and Erofeeva, 2013).

For each survey, an initial depth surface was produced by using all data in that survey as a base for editing. The base surface was created by using the Universal Transverse Mercator (UTM) coordinate system (zone 19N), which was more suitable for the spatial extent of this project than the Geographic Coordinate System of the input files. Several quality control steps were taken to ensure that final base surfaces were free of depth spikes (erroneous data that would impact the quality of the final BTM) prior to the combining of the individual surfaces by using CARIS Base Editor. For example, each survey line was reviewed and edited for erroneous soundings, and adjustments to the speed of sound corrections were applied if required. After preliminary editing was completed, a final depth surface was produced and evaluated again for any remaining artifacts by using both the three-dimensional (3D) subset editor and the 3D viewer within HIPS. If additional edits were required, the final surface was rebuilt and interpolated to fill in any remaining small data gaps (figs. 2 and 3).

The individual surfaces for each survey were combined into one continuous surface by using CARIS Base Editor. During the "Combine" process, the order of the input surfaces was controlled by using one of several queries provided in Base Editor that determine the final value of any overlapping cells from different surfaces. The "Start Date Is Greatest" option was used to determine the cell value of overlapping cells during the combine process. For example, survey 2007-004-FA, with a start date of March 14, 2007, overlapped in areas with survey 2005-019-FA, which had a start date of March 28, 2005. In this case, the final grid used the values from 2007-004-FA where this survey overlapped with 2005-019-FA because the "Start Date Is Greatest" option was used.

The "Combine" function in Base Editor also produces a "contributor" layer that records the extent of the input surface used as a source for each cell in the output surface. This is perhaps the greatest benefit of this method over previous bathymetric compilations in which the user cannot trace the source of the final compilation. This contributor layer is available in the Data Catalog section (in Esri shapefile format) as a record of the input surfaces used with the "Combine" function and ultimately the source of each pixel in the final BTM, using the "Source" attribute in the "PRBathSource" shapefile 
(see the Data Catalog section). The metadata that accompany the spatial data provide additional detailed descriptions of the methods and steps used to produce the final BTM and source polygon.

Controlling the input order and the combination of large overlapping bathymetric surfaces within hydrographic software is a relatively new ability within the CARIS software suite. Similar operations could be performed by using geographic information system (GIS) software; however, the ability to manipulate these data in their near-native form (as soundings) within CARIS software makes the process of combining datasets of different ages and qualities on this broad scale more efficient than working in GIS software. Furthermore, this method facilitates periodic updates to the BTM as new bathymetric data are acquired.

\section{Data Catalog}

If new bathymetric data become available, the data published in this report may be updated, and the grid will be identified by the publication date and version number.

Projection.-These data are published in the UTM coordinate system, zone 19N, WGS 84, with a central meridian of 69 degrees west longitude and a false easting of 500,000. All horizontal and vertical units are in meters.

\begin{tabular}{clcc}
\hline \multicolumn{1}{c}{ Description } & $\begin{array}{c}\text { Identifies the name of the source grid used in } \\
\text { the combine operation }\end{array}$ \\
\hline PRBathSource & 150-meter gridded bathymetry & Download \\
prbathofr150 & ofr2013-1125 prbathofri50.zip
\end{tabular}

\section{Map Plate}

The data published in this report are also presented as plate 1 (60 inches $\times 42$ inches) in portable document file (PDF) format. The data in this map are for cartographic display of the entire Puerto Rico Trench and the northeastern Caribbean region and include base data that were not collected for the BTM published in this report. The areas covered by the BTM published in this report are outlined in the inset map at the lower right of plate 1 . Other data are included for visual display only.

\section{References Cited}

Atwater, B.F., ten Brink, U.S., Buckley, Mark, Halley, R.S., Jaffe, B.E., López-Venegas, A.M., Reinhardt, E.G., Tuttle, M.P., Watt, Steve, and Wei, Yong, 2012, Geomorphic and stratigraphic evidence for an unusual tsunami or storm a few centuries ago at Anegada, British Virgin Islands: Natural Hazards, v. 63, p. 51-84.

Bakun, W.H., Flores, C.H., and ten Brink, U.S., 2012, Significant earthquakes on the Enriquillo fault system, Hispaniola, 1500-2010-Implications for seismic hazard: Bulletin of the Seismological Society of America, v. 102, p. 18-30.

Barkan, Roy, and ten Brink, U.S., 2010, Tsunami simulations of the 1867 Virgin Island earthquakeConstraints on epicenter location and fault parameters: Bulletin of the Seismological Society of America, v. 100, p. 995-1009. 
Chaytor, J.D., and ten Brink, U.S., 2014, Event sedimentation in low-latitude deep-water carbonate basins, Anegada Passage, Northeast Caribbean: Basin Research, 1-26 p.,

http://dx.doi.org/10.1111/bre.12076

Chaytor, J.D., and ten Brink, U.S., 2010, Extension in Mona Passage, northeast Caribbean:

Tectonophysics, v. 493, p. 74-92.

Egbert, G.D., and Erofeeva, L.S., 2013, The OSU TOPEX/Poseidon global inverse solution TPXO (TPXO version 8.0): Oregon State University Web page, accessed July 18, 2013, http://volkov.oce.orst.edu/tides/global.html.

Flores, C.H., ten Brink, U.S., and Bakun, W.H., 2012, Accounts of damage from historical earthquakes in the northeastern Caribbean to aid in the determination of their location and intensity magnitudes:

U.S. Geological Survey Open-File Report 2011-1133, 237 p.

López-Venegas, A.M., ten Brink, U.S., and Geist, E.L., 2008, Submarine landslide as the source for the October 11, 1918 Mona Passage tsunami-Observations and modeling: Marine Geology, v. 254, p. $35-46$.

ten Brink, U.S., 2005,Vertical motions in the Puerto Rico trench and Puerto Rico and their cause: Journal of Geophysical Research, v. 100, no. B-6, 16 p., http://dx.doi.org/ 10.1029/2004JB003459. ten Brink, U.S., Bakun, W.H., and Flores, C.H., 2011, Historical perspective on seismic hazard to Hispaniola and the northeast Caribbean region: Journal of Geophysical Research, v. 116, no. B-12, 15 p., http://dx.doi.org/ 10.1029/2011JB008497.

ten Brink, Uri, Danforth, W.W., and Polloni, C.F., 2013, Final report and archive of the swath bathymetry and ancillary data collected in the Puerto Rico Trench region in 2002 and 2003: U.S. Geological Survey Open-File Report 2006-1210, http://pubs.usgs.gov/of/2006/1210/.

ten Brink, U., Danforth, W., Polloni, C., Andrews, B., Llanes, P., Smith, S., Parker, E., and Uozumi, T., 2004, New seafloor map of the Puerto Rico trench helps assess earthquake and tsunami hazards in the northwest Caribbean: Eos, v. 85, no. 37, p. 349, 354.

ten Brink, Uri, Danforth, William, Polloni, C.F., Parker, C.E., Uozumi, Toshihiko, and Williams, G.F., 2005, Project PROBE leg II-Final report and archive of swath bathymetric sonar, CTD/XBT and GPS navigation data collected during USGS cruise 03008 (NOAA cruise RB0303) Puerto Rico Trench 18 February-7 March, 2003: U.S. Geological Survey Open-File Report 2004-1400, DVDROM, http://pubs.usgs.gov/of/2004/1400/.

ten Brink, Uri, Dillon, William, Frankel, Arthur, Mueller, Charles, and Rodriguez, R.W., 1999, Seismic and tsunami hazards in Puerto Rico and the Virgin Islands: U.S. Geological Survey Open-File Report 99-353, http://pubs.usgs.gov/of/1999/of99-353/.

ten Brink, U.S., Geist, E.L., and Andrews, B.D., 2006a, Size distribution of submarine landslides and its implication to tsunami hazard in Puerto Rico: Geophysical Research Letters, v. 33, no. 11, 4 p., http://dx.doi.org/10.1029/2006GL026125.

ten Brink, Uri, Geist, E.L., Lynett, Patrick, and Andrews, Brian, 2006b, Submarine slides north of Puerto Rico and their tsunami potential, in Mercado-Irizzary, Aurelio, and Liu, Philip, eds., Caribbean tsunami hazard: Singapore, World Scientific Publishing Co. Pte. Ltd., p. 67-90.

ten Brink, Uri and Lin, Jian, 2004, Stress interaction between subduction earthquakes and forearc strikeslip faults-Modeling and application to the northern Caribbean plate boundary: Journal of Geophysical Research, v. 109, no. B-12, 15 p., http://dx.doi.org/10.1029/2004JB003031.

ten Brink, U.S., and López-Venegas, A.M., 2012, Plate interactions in the NE Caribbean subduction zone from continuous GPS observations: Geophysical Research Letters, v. 39, http://dx.doi.org/10.1029/2012GL051485. 
ten Brink, U.S., Marshak, Stephen, and Granja Bruña, J.-L., 2009, Bivergent thrust wedges surrounding oceanic island arcs - Insight from observations and sandbox models of the northeastern Caribbean plate: Geological Society of America Bulletin, v. 121, p. 1522-1536.

ten Brink, U.S., Worley, C., Smith, S., Stepka, T., and Williams, G., 2006c, Project PROBE Leg IReport and archive of multibeam bathymetry and acoustic backscatter, CTD/XBT and GPS navigation data collected during USGS Cruise 02051 (NOAA Cruise RB0208) Puerto Rico Trench, September 24, 2002 to September 30, 2002: U.S. Geological Survey Open-File Report 2005-1066, DVD-ROM, http://pubs.usgs.gov/of/2005/1066/. 


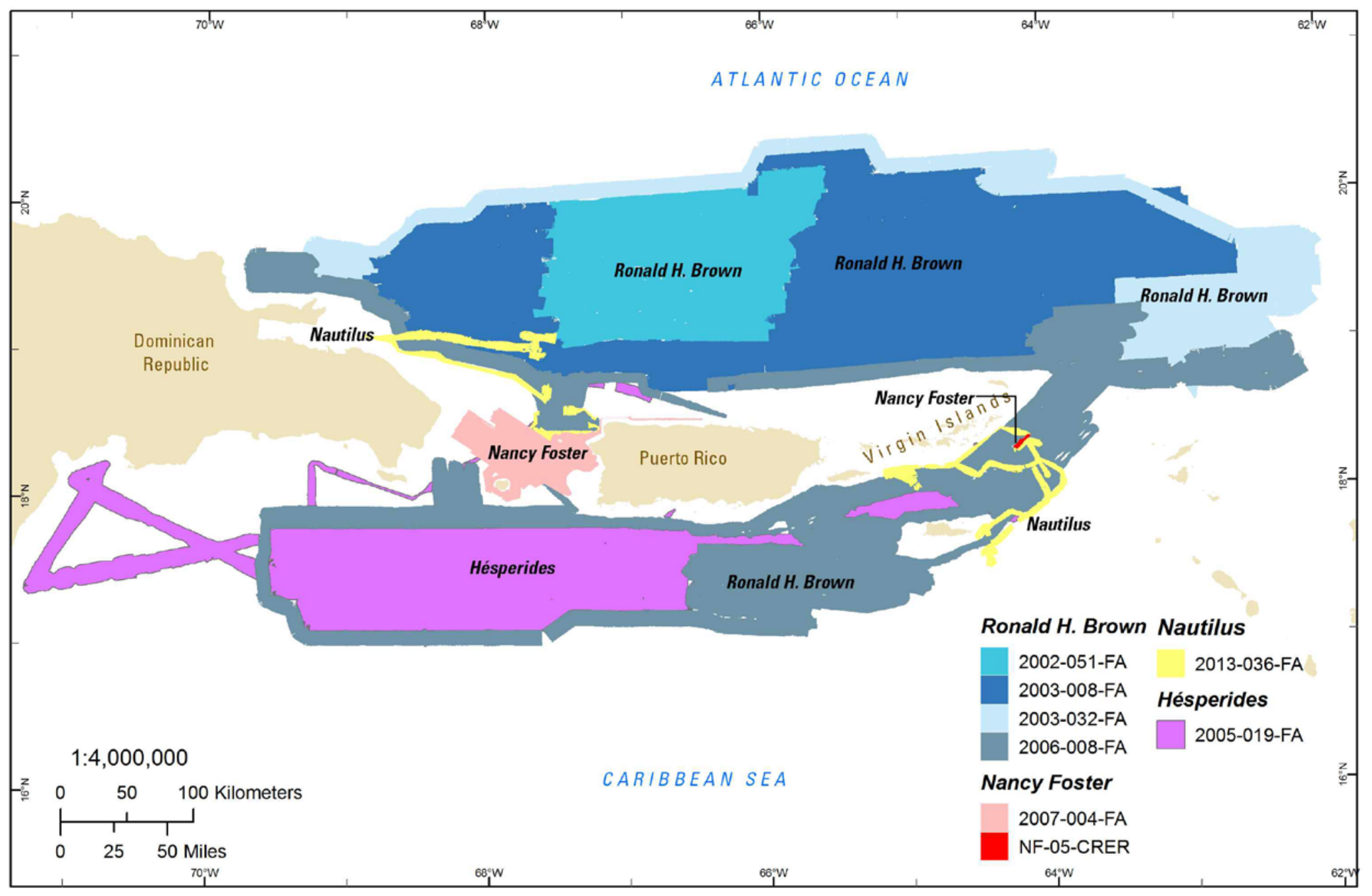

Figure 1. Map showing source surveys (color coded by survey vessel) used to compile the final bathymetric terrain model and published as an Esri shapefile in this report. Surveys are also listed in table 1. Land in tan color is for base-map purposes only and not published in this report. Data are from the U.S. Geological Survey, and Esri. 

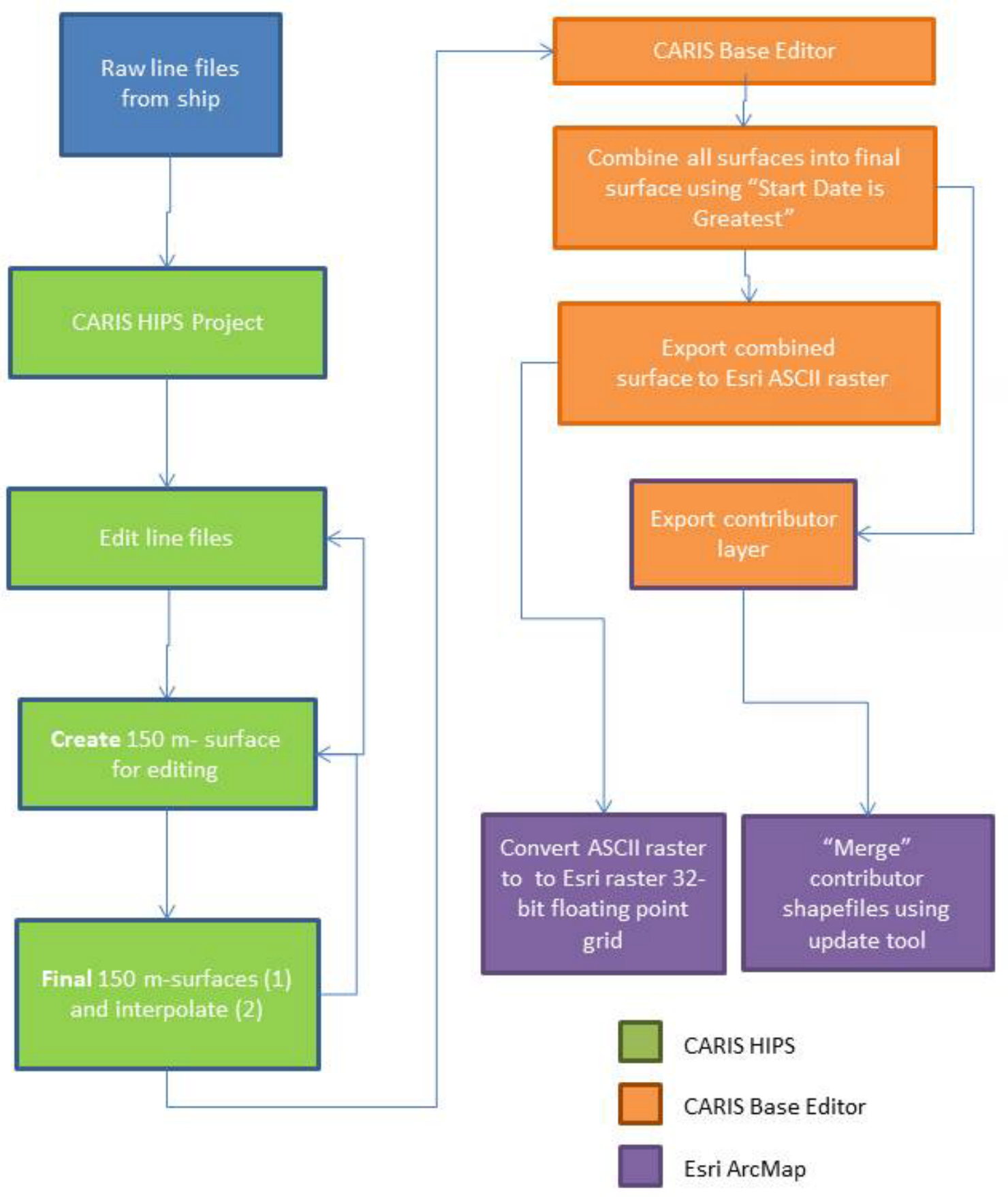

Figure 2. Diagram showing the general data flow used to process the raw multibeam files into the final data products published in this report. HIPS, Hydrographic Information Processing System; m, meter; ASCII, American Standard Code for Information Interchange. 


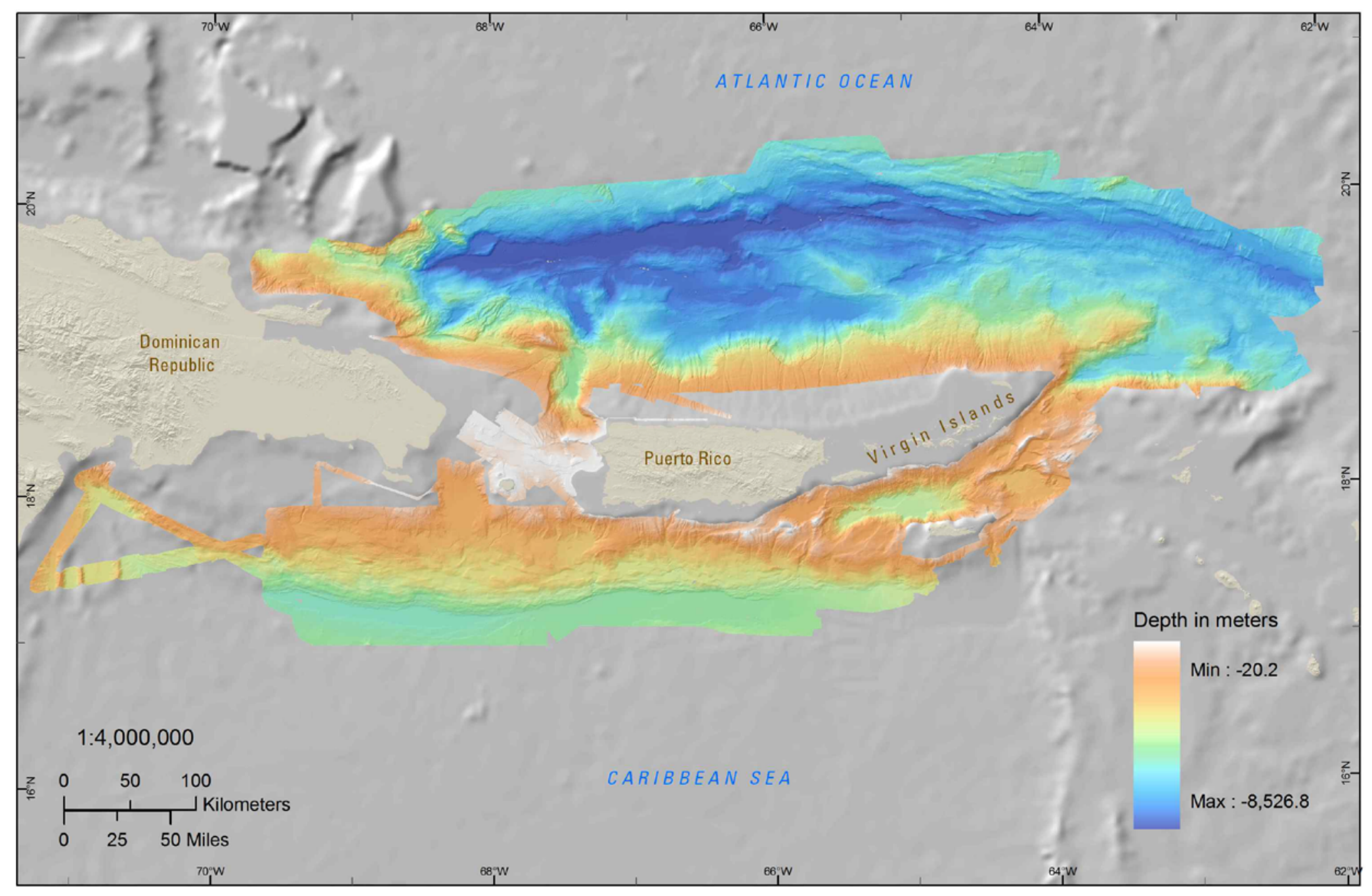

Figure 3. Map of the Puerto Rico Trench and surrounding areas showing the extent of the bathymetric terrain model published in this report. Elevations in tan and gray-scale hillshade (showing the landmasses and the seafloor area outside the study area) are for base map purposes only and not published in the report. Data are from the U.S. Geological Survey, the National Oceanic and Atmospheric Administration and Esri. max, maximum; min, minimum. 
Table 1. Bathymetric surveys in the area around the Puerto Rico Trench in the northeastern Caribbean.

[The U.S. Geological Survey (USGS) field activity number indicates that USGS scientists participated in the survey. Survey NF-07-05-CRER did not include USGS scientists and does not have a USGS field activity number. The National Geophysical Data Center (NGDC) cruise name indicates that the raw line files are archived with NGDC and were issued a NGDC cruise name. USGS, U.S. Geological Survey; NOAA, National Oceanic and Atmospheric Administration; NGDC ID, National Geophysical Data Center identification number; $\mathrm{kHz}$, kilohertz; RV, research vessel; EV, exploration vessel; NA, not available]

\begin{tabular}{|c|c|c|c|c|c|c|c|}
\hline $\begin{array}{l}\text { USGS field } \\
\text { activity }\end{array}$ & Vessel & NGDC cruise name & NGDC_ID & Start date & End date & $\begin{array}{l}\text { Frequency } \\
(\mathrm{kHz})\end{array}$ & Archive \\
\hline 2002-051-FA & $\begin{array}{l}\text { NOAA ship Ronald H. } \\
\text { Brown }\end{array}$ & RB0208 & 03750011 & 24-Sep-02 & 30-Sep-02 & 12 & $\begin{array}{l}\text { http://surveys.ngdc.noaa.gov/mgg/MB/ocean/ronald h._brown/ } \\
\underline{\text { RB0208/multibeam/data/version1/MB/ }}\end{array}$ \\
\hline 2003-008-FA & $\begin{array}{l}\text { NOAA ship Ronald } H . \\
\quad \text { Brown }\end{array}$ & RB0303 & 03750010 & 21-Feb-03 & 7-Mar-03 & 12 & $\frac{\text { http://surveys.ngdc.noaa.gov/mgg/MB/ocean/ronald h. brown/ }}{\text { RB0303/multibeam/data/version1/MB/ }}$ \\
\hline 2003-032-FA & $\begin{array}{l}\text { NOAA ship Ronald } H . \\
\text { Brown }\end{array}$ & RB0305 & NEW2055 & 28-Aug-03 & 4-Sep-03 & 12 & $\frac{\text { http://surveys.ngdc.noaa.gov/mgg/MB/ocean/ronald h._brown/ }}{\text { RB0305/multibeam/data/version1/MB/ }}$ \\
\hline 2005-019-FA & RV Hespérides & NA & NA & 28-Mar-05 & 17-Apr-05 & 12 & $\begin{array}{l}\text { http://woodshole.er.usgs.gov/operations/ia/public_ds_info.php? } \\
\text { fa }=2005-019-\text { FA }\end{array}$ \\
\hline 2006-008-FA & $\begin{array}{l}\text { NOAA Ship Ronald H. } \\
\text { Brown }\end{array}$ & RB0604 & NEW2049 & 3-May-06 & 19-May-06 & 12 & $\frac{\text { http://surveys.ngdc.noaa.gov/mgg/MB/ocean/ronald h. brown/ }}{\underline{\text { RB0604/multibeam/data/version1/MB/ }}}$ \\
\hline 2007-004-FA & $\begin{array}{l}\text { NOAA Ship Nancy } \\
\text { Foster }\end{array}$ & NF-07-04-PMEL & NEW1542 & 14-Mar-07 & 26-Mar-07 & 95 & $\frac{\text { http://surveys.ngdc.noaa.gov/mgg/MB/ocean/nancy foster/NF- }}{\text { 07-04-PMEL/multibeam/data/version1/MB/ }}$ \\
\hline NA & $\begin{array}{l}\text { NOAA Ship Nancy } \\
\quad \text { Foster }\end{array}$ & NF-07-05-CRER & NEW1543 & 28-Mar-07 & 4-Apr-07 & 95 & $\begin{array}{l}\text { http://surveys.ngdc.noaa.gov/mgg/MB/ocean/nancy foster/NF- } \\
\text { 07-05-CRER/multibeam/data/version1/MB/ }\end{array}$ \\
\hline 2013-036-FA & EV Nautilus & NA & NA & 5-Oct-13 & 18 -Oct-13 & 30 & NA \\
\hline
\end{tabular}


Prepared by the Pembroke Publishing Service Center.

For more information concerning this report, contact:

Director

Woods Hole Coastal and Marine Science Center U.S. Geological Survey

384 Woods Hole Road

Quissett Campus

Woods Hole, MA 02543-1598

WHSC_science_director@usgs.gov

508-548-8700 or 508-457-2200

or visit our Web site at:

http://woodshole.er.usgs.gov/ 
